\title{
The Effect of Career Development and Motivation on Performance of Agricultural Extension Agents in Banten Province, Indonesia
}

\author{
Siti Rochaeni $^{\mathrm{a}, *}$, Yon Girie Mulyono ${ }^{\mathrm{b}}$, Dini Anggraenic \\ ${ }^{a}$ Department of Agribusiness, Faculty Science and Technology \\ Syarif Hidayatullah State Islamic University Jakarta \\ Tangerang Selatan, Indonesia \\ *E-mail: siti.rochaeni@uinjkt.ac.id
}

\begin{abstract}
This study aims to (1) analyze the effect of career development on the performance of agricultural instructor in Banten; (2) analyze the effect of motivation on the performance of agricultural instructor in Banten; (3) analyze the effect of career development and motivation on the performance of agricultural instructor in Banten. This study was conducted from September-November 2016 in the province of Banten through quantitative approach. The sample of 88 agricultural agents was employed through Stratified Proportionate Random Sampling technique in Tangerang districts, including, Pandeglang, Serang Regency, Lebak, and Serang. The finding indicated that the career development and motivation variables significantly affect the performance of agricultural extension agents in Banten province.
\end{abstract}

Key words: Career Development, Motivation, Performance, Agricultural extension agents

\section{Introduction}

Indonesian agriculture has a very diverse problem, one of which is the lack of knowledge of farmers in terms of producing and processing in a modern and more efficient way, absorbing high technology and accessing information therefore farmers' productivities and welfare are low. One of the ways in which the government tackles this problem is with agricultural extension programs. Good agricultural extension agents can improve farmers' skills, productivities and welfare. Banten Province is the 10th largest rice production center in Indonesia. However, the province currently faces a problem with the decreasing number of agricultural extension agents (table 1).

Table 1. Number of Agricultural Extension Agents in Banten

\begin{tabular}{|l|l|l|l|l|}
\hline \multirow{2}{*}{ No. } & \multirow{2}{*}{ Districts/Cities } & \multicolumn{3}{|c|}{ Number of Agricultural Extention } \\
\cline { 3 - 5 } & & $\mathbf{2 0 1 3}$ & \multicolumn{1}{|c|}{$\mathbf{2 0 1 4}$} & $\mathbf{2 0 1 5}$ \\
\hline 1 & Pandeglang & 270 & 259 & 257 \\
\hline 2 & Lebak & 207 & 204 & 203 \\
\hline 3 & Tangerang & 125 & 106 & 106 \\
\hline 4 & Serang & 161 & 144 & 144 \\
\hline 5 & Tangerang & 5 & 7 & 7 \\
\hline 6 & Cilegon & 15 & 15 & 15 \\
\hline 7 & Serang & 23 & 16 & 16 \\
\hline 8 & South Tangerang & 12 & 10 & 10 \\
\hline 9 & Banten & 13 & 11 & 11 \\
\hline Total & & 831 & 772 & 769 \\
\hline
\end{tabular}

Source: [1]
Based on Table 1, it is implied that the number of agricultural extension agents in 2013 was 831 people, then the number was decreased in 2014 by 772 people and finally it was decreased in 2015 to 769 people. Decrease in the number of extension agents will affect the ability of extension agents in carrying out their duties. With this decrease, the ratio between the number of villages and the number of agricultural extension agents in Banten Province is even greater. Data indicated that the number of agricultural extension agents in Banten Province in 2015 amounted to 769 people while the number of villages in Banten Province was 1,273 villages [1]. Thus, in this study, we investigated the effect of career development and motivation on the performance of agricultural extension agents in Banten Province. Career development and good motivation will encourage agricultural extension agents to grow and develop. A clear career pattern on appointment of agricultural extension agents will provide security for their career development. Finally, the existence of a secure career pattern will give a positive effect on the performance of the agricultural extension itself.

\section{Research Method}

This research employed primary and secondary data. Primary data were obtained directly from interviews with 88 agricultural extension agents in Serang, Tangerang, Pandeglang, and Lebak Regency through Stratified Proportionate Random Sampling Method. While the secondary data were obtained from the Agency for Food Security and Counseling (BKPP) Banten Province, books, Central Bureau of Statistics (BPS), journals and data from other agencies concerned. Data were analyzed by employing multiple linear regression with the following model [2]:

\section{Where:}

$$
\mathrm{Y}=\mathrm{a}+\mathrm{b} 1 \mathrm{X} 1+\mathrm{b} 2 \mathrm{X} 2+\mathrm{e}
$$

Y : Performance of agricultural extention agents

$\mathrm{X} 1$ : Career development

X2 : Motivation

a. : Intercept

b. : Coefficient

e. : error 
2. Results And Discussion

3.1 Factors Affecting The Performance of Agricultural Extension Agents in Banten Province, Indonesia

The dependent variable $(\mathrm{Y})$ in this research is the performance of agricultural extension in Banten Province, while the independent variable $(\mathrm{X})$ is career development (X1) and motivation (X2). This study uses a confidence level of $90 \%$. The effect of career development and motivation on the performance of agricultural extension agents in Banten Province is indicated in the table 2 below:

Table 2. The effect of career development and motivation on the performance of agricultural extension agents in Banten Province

\begin{tabular}{|l|l|l|l|c|}
\hline \multicolumn{1}{|c|}{ Variables } & \multicolumn{1}{c|}{ Coeff. } & \multicolumn{1}{c|}{ Tvalue } & Fvalue & Sig. \\
\hline Intercept & 9,709 & 3,229 & 66,758 & 0,002 \\
\hline $\begin{array}{l}\text { Career } \\
\text { development }\end{array}$ & 0,580 & 7,276 & & 0,000 \\
\hline Motivation & 0,450 & 4,746 & & 0,000 \\
\hline $\mathrm{R}^{2}=0.611$ & & & \\
\hline Sig $=0.100$ & & \\
\hline Ttable $=1.66298$ \\
\hline Ftable $=2.37(\alpha=0,1)$ \\
\hline
\end{tabular}

Source: Primary Data, 2016 (Processed)

\subsection{The Effect of Career Development (X1) on Performance (Y)}

Based on the table 2, the career development (X1) has a positive effect on the performance of agricultural extension agents $(\mathrm{Y})$. The regression coefficient for career development $(\mathrm{X} 1)$ is positive of $0.580(\alpha=0.01)$. This positive sign indicates a direct relationship between career development and agricultural extension performance. This result is in accordance with the prior research [3] and [4] where a person's ability to determine work performance. Good experience and ability will enhance the organization's ability to compete and adapt to competitively environmental changes related to individual career development as well as to get focus and improve performance.

Based on the results of interviews with agricultural extension agents in this study in terms of career development on agricultural extension performance, as much as $2.2 \%$ of respondents strongly agree that career developments in the Banten Provincial Agricultural Training Center in the form of excellent training affect the performance of extension workers, while $45.51 \%$ agree, $23.27 \%$ doubt, $14.16 \%$ disagree and $3.4 \%$ strongly disagree that career development affect the performance. This indicates that career development in the agricultural extension of Banten Province has been running well.

\subsection{The Effect of Motivation (X2) on Performance (Y)}

Based on table 2, the motivation variable (X2) has a positive effect on the performance of agricultural extension agents (Y). The regression coefficient for motivation (X2) has a positive value of $0.450(\alpha=0.01)$. This positive sign indicates a direct relationship between motivation and the performance of agricultural extension agents in Banten Province. These results are in accordance with the prior studies [5], [6], [7] and [8] where there is a positive relationship between motivation and performance. This means that employees who have high achievement motivation tend to have high performance, otherwise those who have low performance is due to low motivation.

Based on the results of interviews with agricultural extension agents in this study in terms of motivation on agricultural extension performance, as many as $18.20 \%$ of respondents strongly agree that they are motivated to improve performances, while $33.38 \%$ agree, $27,31 \%$ doubt, $8,9 \%$ disagree and $2,2 \%$ strongly disagree due to lack of motivation therefore the performances are considered less good. This indicates that the overall motivation of agricultural extension agents of Banten Province is moderate.

\subsection{The Effect of Career Development and Motivation on the Performance of Agricultural Extension Agents in Banten Province}

F-test is employed to determine whether the independent variables together have effects on the performance of agricultural extension agents in Banten Province. This test is carried out by comparing F-value with F-table or by comparing significant values with $\alpha$ values. Based on Table 2 above, it is implied that the value of F-value of 66.758 is greater than F-table of 2.37. Then the null hypothesis is rejected, which means independent variables observed with $90 \%$ confidence level that is career development and motivation have significant effects on performance of agricultural extension agents in Banten province. The $\mathrm{R}^{2}$ value of 0.611 indicates that as much as $61 \%$ of the agricultural extension agents' performances can be explained by career development and motivation.

\section{Conclusion and Recommendation \\ 4.1 Conclusion}

Based on the above analysis results, it can be concluded as follows:

3. There is a positive effect of career development on the performance of agricultural extension agents in Banten Province.

4. There is a positive effect of motivation on the performance of agricultural extension agents in Banten Province.

5. There is a mutual effect of career development and motivation on the performance of agricultural extension agents in Banten Province. The effect of career development on agricultural extension performance is greater than motivation.

\subsection{Recommendation}

Based on the conclusions above, we give some recommendations as follows: 
1. A Need for promotion policies and clear career developments. Recruitment should be held once every 1 year and promotion is held no later than 4 years.

2. Career planning of agricultural extension agents needs to be based on task specifications and clear standard of tasks in accordance with the main tasks and functions of agricultural extension agents.

3. A need to overcome the problem of adjustment of extension career path according to education. It is necessary to develop training of career transfer for extension agents who have completed bachelor and master education, as well as trainings to increase professionalism extension.

\section{References}

[1] Badan Ketahanan Pangan dan Penyuluhan Provinsi Banten Tahun (BPKP). 2015. Data Penyuluh Provinsi Banten 2015. Banten: Badan Ketahanan Pangan dan Penyuluhan.

[2] Sunyoto, D. 2010. Uji Khi Kuadrat \& Regresi untuk Penelitian. Yogyakarta: Graha Ilmu.
[3] Ilyas, Y. 2002. Kinerja: Teori, Penilaian, dan Penelitian. Depok: Pusat Kajian Ekonomi Kesehatan FKMUI.

[4] Rahajeng, D., Y. 2008. Pengaruh Kepemimpinan dan Pengembangan Karir terhadap Kinerja Pegawai Direktorat Jenderal Imigrasi [Thesis]. Universitas Indonesia, National Resilience Study Program, University of Indonesia.

[5] Sudarmanto. 2009. Kinerja Dan Pengembangan Kompetensi SDM : Teori, Dimensi Pengukuran, dan Implementasi dalam Organisasi. Yogyakarta: Pustaka Pelajar.

[6] Munandar, A.S. 2001. Psikologi Industri dan Organisasi. Depok: Penerbit Universitas Indonesia (UI Press).

[7] Bokings, H.,D.,A. 2013. Pengaruh Motivasi terhadap Kinerja Aparat Badan Pelaksana Penyuluhan Pertanian Perikanan Dan Kehutanan (BP4K) Kota Gorontalo [Bachelor Thesis]. Gorontalo University.

[8] Andiyanto, W. 2011. Pengaruh Motivasi Kerja dan Kepemimpinan terhadap Kinerja Pegawai pada Badan Keluarga Berencana dan Pemberdayaan Perempuan Kabupaten Manggarai - Flores Nusa Tenggara Timur [Bachelor Thesis]. Faculty of Economics, Diponegoro University. 